\title{
The Contribution of Professional Competence through the Work Discipline and Performance to Teacher Work Productivity in Public Elementary School of
}

\section{Tabunganen Subdistrict, Barito Kuala}

\author{
Wahdatan Nisa *, Aslamiah, M. Saleh \\ Master Program of Education Management, Universitas Lambung Mangkurat, Banjarmasin 70123, \\ Indonesia
}

\section{Article history:}

Submission August 2020

Revised August 2020

Accepted September 2020

*Corresponding author:

E-mail: wahnisa2@gmail.com

\begin{abstract}
The greater challenges in the future require teachers to increase work productivity. The purpose of this research is to describe and analyze how much the direct and indirect contribution of professional competence through the work discipline and teacher performance to work productivity. This research was conducted with a quantitative approach using the path analysis method. The population in this research was totaling 102 teachers of Public Elementary Schools in Tabunganen Sub-District with a work period over 5 years. Samples were taken as many as 81 people. Sampling used by a simple proportionate sampling technique data collection uses instruments was a questionnaire. The results of this research showed that there are direct contributions of 1) professional competence, work discipline, performance to work productivity; and indirect contributions of 2) professional competence through the work discipline to work productivity; 3) professional competence through performance to work productivity. Suggestions for teachers to upgrade professional competence, to improve discipline in time, and to produce useful scientific work to improve the teacher work productivity.
\end{abstract}

Keywords: professional competence 1, work discipline 2, performance 3, work productivity 4

\section{Introduction}

The educational system should be prepared a good quality of human resources that can be competitive. If the Indonesian human resource has a good qualification of education and competence, so they will be people who have productivity (Suriansyah, 2015). To be able to have high performance across individual, group, organization, and system levels, the performance management systems could be reoriented (Blackman, West, O'Flynn, Buick, \& O'Donnell, 2015). Also, in an era of globalization and challenging circumstances, performance management is becoming a popular term and a new organizational ideology across the world (Kim, 2016). Hence, education must be a highlight to answer the global challenge because innovation can be developed through education to get this aim. Furthermore, the development of education will also influence the development of civilization (Hamda \& Dalle, 2011). The change of paradigm the implementation of the National Education System from centralistic to decentralization is an effort to increases the quality of education (Rizalie, 2017). Quality of education depends on the participation of the teachers. The teachers should have a good level of productivity and have a high ability to cope with the changes faced. For instance, there should be training programs for teachers as well as the administrators and investments to enhance the quality of the educational inputs (Gonzalez, Karoly, Constant, Salem, \& Goldman, 2008). The environment is also a pervasive factor in influencing all organizational perspectives as it is the 
source of external pressures (Emmerichs, Marcum, \& Robbert, 2004).

The research that was conducted by (Engelbrecht, 2016) suggests that it is difficult to measure the work productivity of the teacher because of the contextual factor and external factor. But, he has suggested that it can be measured with four approaches that are: teacher subject competency tests, the role of the principal, the role of the department of education, value-added model. Besides, in some prominence cases of government performance measurement and management, the vital component was an explicit definition of performance that normally available in the authorizing statute (Klerman, 2005).

The effort to know how much the productivity of teachers to work together and how much effectiveness to get the purpose needs an assessment of performance. It can help a teacher to be responsible for her job. Teacher's performance is a very important factor that influences the management learning process at the school (Normianti, Aslamiah, \& Suhaimi, 2019). Performance is very related to productivity because it can be an indicator to determine a level of productivity in an organization (Wahyudi, 2012; Kelimeda, Hairudinor, Ridwan, \& Dalle, 2018). Consequently, the highest priority for educational policymakers and practitioners is to staff all classrooms with effective teachers to educate students to be productive citizens of a knowledge-based society (Synar \& Maiden, 2012).

Professional competence is reflected by capability and skill. Since the teacher has a professional authority that has always been perceived as an educated person that $\mathrm{s} / \mathrm{he}$ is expected to have to know more in the way of subject matter than just what they are charged with teaching (Kirby, McCombs, Barney, \& Naftel, 2006). It cannot be separated from the guidance and support of the headmaster to motivate the performance growth of the teacher. Because, one of the competence that a leader should have is the capability to motivate the team (Aslamiah, 2012). Reformers have theorized that decentralizing education to the lowest level possible would create greater efficiency and productivity by eliminating unnecessary bureaucracy and allowing leaders closest to students to make decisions about how resources would be used (Carpenter \& Noller, 2010). Headmaster also has a chance to forge a strong partnership between adults that are the teachers, parents, and community members to develop a unified adult voice in support of kids (Weintraub, 2012). For example, in a music school, both music teachers and principals shared ideas to improve music teacher evaluation, including the need for evaluators with music-content expertise (Berberick, Clementson, Hawkinson, \& Rolandson, 2016). Characteristics of teacher work productivity showed from the technical skill and professional competence of the teacher (Susanto, 2016). As it has been researched by Mizell in 2002, many middle school advocates believe that improving education for middle school students hinges on improving the competence of teachers (Juvonen, Le, Augustine , \& Constant, 2004). So, work productivity is influenced by teacher professional competence. The result shows that it is a positive and significant relationship between professional competence and work productivity. It is in line with the fact that professional skills enhancement in training adults becomes a crucial thing in the organization's development (Butter \& Hermanns, 2011), as well as in school. Hence, competence is an important factor to increase teacher work productivity (Hamdani, 2017).

Teachers that have good control of professional competence should have a work discipline that can be moving the competence to keep on growing. A person's vocational or professional competence is defined by the sum of his or her observed work behaviors in an authentic situation (Van Weeren, 2004). It requires discipline to display professionalism. Without discipline, a professional will be difficult to do the maximum result of the task (Suriansyah, 2015). In other words, it may be work situations and experiences through which learning takes place (Cohen-Scali, 2012). Transformation in the organization and content of work in turn affect the key qualifications 
expected at both a technical and behavioral level. Thus, to build teachers' work discipline school should create a situation and an environment that support that behavior. That kind of situation and environment that builds discipline can be created by the support of sufficient school facilities (Zachos, Delaveridou, \& Gkontzou, 2016).

Also, Hariandja (2005) has said that work discipline is an important factor in increasing productivity. Discipline is important as the era will never stay the same but the productivity needs to stay in place. It is since one-day different students will come and they will need new skills and competencies from the teachers $(\mathrm{Ng}$, Schweitzer, \& Lyons, 2010). This is made clear by the results which concluded that there was a contribution of work discipline to teacher's work productivity in Public Elementary School in the Karang Intan Subdistrict.

In addition to effect, work productivity is teacher performance. Regarding the performance of Armstrong and Baron (Suriansyah, 2014) explained that performance is "implementation of work and results of implementation carried out by someone about what is done and how to do it". For example, in the new era of technology, performance has been linked to how teachers can understand and apply technology in educational contexts (Sabzian, Gilakjani, \& Sodouri, 2013). Hence, improving student performance can be done by improving the teacher's performance because when the teachers always do their best, students will experience a better learning process (Tóth-Pjeczka, Rapos, \& Szivák, 2019). In other words, teachers' performance will automatically enhance students' achievement (Costaa, Cardosob, Limac, Ferreirad, \& Abrantes, 2015).

Gomes (2005) has defined that performance is the result of the work with efficiency and effectiveness which relates to productivity. People who have a good level of performance can be seen as productive people. This because the performance has a relation to the level of productivity. Productivity itself, according to Dunleavy (Dunleavy, 2015) has been an important concept in the private sector. So, it can be important as well in the public sector including school. Productivity can be defined as well as efficiency in a production that it is the amount of output obtained from a given set of inputs (Newman, Page, Rand, Shimeles, \& Söderbom, 2016). For educational institutions such as public schools, efficiency is defined $s$ the relationship between educational inputs and educational outcomes, specifically, the maximization of the former for an increased amount of the latter (Houck, Rolle, \& He, 2010).

The low productivity in Public Elementary School teachers in Tabunganen Subdistrict is assumed because the professional teacher, work discipline, and performance have not yet at a high level for growth. The average of UKG value in 2015 is under 55 and still need continuous development. It showed that there were less research and scientific work, some of the teachers have a low interest to continue a level up of education. It is in contrast with the growing work productivity that is expected. Meanwhile, without upgrading skills, the performance will never be firmed and productivity will never have a chance to catch-up (Darko, Occhiali, \& Vanino, 2018).

However, urgently teachers need to be able to improve work productivity through efforts to improve performance, increase the work discipline, and professional competence to achieve the best quality of education.

\section{Material and Methods}

This research uses a quantitative approach. The quantitative approach depends on material data (Bode, 2012). This approach method usually using a sample taken from the population as data. The population of the research was 102 people at the Public Elementary School in Tabunganen Sub-district. The sample was taken from 81 teachers in 19 schools selected by simple proportionate sampling. Data was collected using a four-scale model questionnaire that was tested for validity and reliability. There are two questionnaires used in this study namely the work discipline questionnaire and work productivity questionnaire. Then, professional competence data was collected from UKG value and teacher performance data was collected from PKG. Furthermore, hypothesis testing was using path analysis with the assist SPSS 22 program. 


\section{Results and Discussion}

The results of the respondent's descriptive statistical analysis of the research variables, namely professional competence, work discipline, performance, and work productivity are shown in Table 1 which includes the mean, standard deviation, and categories. Based on Table 1 it is known that the work discipline is very high and the work productivity had a medium category. This proves that the teacher's work productivity of public elementary schools in the Tabunganen Subdistrict still needs to be improved.

The results of the classical assumptions test include residual normality data tests using the Kolmogorov-Smirnov one-sample method showing all the variables are normally distributed. The significant value shown in the output is 0,100 . It states that variable data is normally distributed because it has a value greater than a significant rate of 0.05 .

Homogeneity test results indicate that all variables used are from the same population or homogeneous variance. The results of the multicollinearity test showed the tolerance value of each variable was more than 0.1 and the VIF value was more than 10 . Besides, heteroskedasticity test results on all variables showed a significance value of more than 0.05 .

The results of path analysis as shown in Table 2, Table 3, and Table 4 are used to answer ten research hypotheses that have been formulated and the decision of the analysis results can be seen in Table 5 and Table 6 . Table 5 is a summary of the decision of hypothesis 1 to hypothesis 6 with a critical value of less than 0.05 , then the hypothesis is accepted. Table 6 is a summary of the decision of testing hypothesis 7 to hypothesis 10 which is an indirect contribution.

From Figure 1, it can be seen that there is a direct contribution of professional competence to work productivity by 0,182 . Teachers' work productivity was seen from teachers' work quality, dedication to their job, their effort to professionalism, their PTK, and training and workshop. The higher of professional competence, the higher of work productivity. The results of this study state that there is a contribution of professional competence to work productivity of Senior high school in the Kandangan Subdistrict. Besides that, there is a direct contribution of professional competence to teacher performance in Public Elementary School in Tabunganen Subdistrict by 0,269.

This study is in line with Kadarisman (2011) which states that there is a direct relationship between the professionalism $\mathrm{s}$ and the performance of someone. Professional teachers certainly have professional, pedagogical, social, and personal competencies that must be possessed by a teacher. So that the higher the level of professionalism of a teacher, the better the performance (Novozhenina \& Pinzon.M.M, 2018). Thus, teacher education programs must implement more innovative and robust programs focused on learning outcomes as constant with time as a variable (Bull, Patterson, Dunston, Wilbur, \& Simpson, 2017). Teachers' professionalism can get higher by improving their competence in using current technology for teaching (Fenwick \& Edwards, 2016). Furthermore, professional competence also has an influence in increasing teachers' work discipline. There is a contribution of professional competence to work discipline by 0,246. According to Suprihatiningrum (2016) states that professional teacher has a discipline skill effectively. These states are in line with Ndugu (2014) suggesting that the higher the teacher quality, the higher the productivity. Teacher quality aspects such as qualification are a relationship with the professional competence of the teacher. Thus, schools should create a good relationship between the teachers and students at school, where the teachers and the students can collaborate in the teaching and learning process. By doing activities that bound the students and their teachers in a good relationship will build the effect of interdependent, and they mutually will influence the quality of the instruction process (Krajewska, 2019).

There is a direct contribution of work discipline to work productivity by 0,588 . Discipline has a relationship with the learning effectiveness of the teacher to get better quality. This improvement influence on teacher work productivity at the school. A teacher who has a high level of discipline also can work with 
effectiveness, have a positive habit, and want to contribute to increasing the quality of education Yusuf, Olufunke, \& Valentine (2015).

Thus, maintenance of discipline also affects a teacher's productivity. The results of this study are in line with Hariandja (2005) which states that work discipline is an important factor in increasing productivity. Teachers, as identity, are always being produced, in a state of becoming, changing, and shifting in response to different social contexts and dynamics (Santoro, Reid, Crawford, \& Simpson, 2012). Hence, discipline is needed. Another factor that contributes to an increase in work productivity is performance. There is a direct contribution of performance to work productivity by 0,172 . There is a contribution of performance to work productivity. If the teacher has a good understanding of the field of study or material to be taught, the teacher's performance will be good (Ahmed, 2012). To be able to identify their professional identity will enhance their professionalism so that they can fulfill every demand of the school and the students (YaminAli, 2019). Likewise, Susanto (2016) states that the implementation of work productivity is a good treatment through performance. Policies are needed to revise the professional profile of teachers at all levels in the relation to work productivity including improving the performance of the students (Lauwers, 2019). So, professional competence, work discipline, and performance are contributed to increasing teacher's work productivity in Tabunganen Subdistrict.

Table 1. Mean, standard deviation, and categories of research variables

\begin{tabular}{lccc}
\hline \multirow{2}{*}{\multicolumn{1}{c}{ Variable }} & \multicolumn{3}{c}{ Descriptive } \\
\cline { 2 - 4 } & Mean & Standard Deviation & Category \\
\hline Professional Competence & 63.38 & 11.21 & Good \\
Work Discipline & 95.43 & 6.383 & Very good \\
Teacher Performance & 85.51 & 4.101 & Good \\
Work Productivity & 91.51 & 8.420 & Medium \\
\hline
\end{tabular}

Table 2. Results of path analysis in structure model 1

\begin{tabular}{lllllll}
\hline Structural 1 & Professional Competence for Work Discipline & & & \\
\hline Variable & Path coeffi-cient & $\boldsymbol{t}$ & Sig & R2 & $\boldsymbol{F}$ & Sig \\
\hline Professional & 0.246 & 2.255 & 0.027 & 0.060 & 5.085 & 0.02 \\
Competence & & & & & & 7 \\
\hline
\end{tabular}

Table 3. Results of path analysis in structure model 2

\begin{tabular}{lllllll}
\hline \multicolumn{3}{l}{ Structural 2 Professional Competence, Work Discipline on Teacher Performance } \\
\hline Variable & Path coeffi-cient & $\boldsymbol{t}$ & Sig & R2 & $\boldsymbol{F}$ & Sig \\
\hline $\begin{array}{l}\text { Professional Com- } \\
\text { petence }\end{array}$ & 0.269 & 2.481 & 0.015 & 0.072 & 6.153 & 0.015 \\
\hline Work Discipline & -0.006 & -0.053 & 0.958 & 0.072 & 3.039 & 0.054 \\
\hline
\end{tabular}

Table 4. Results of path analysis in structure model 3

\begin{tabular}{lllllll}
\hline $\begin{array}{l}\text { Structural } 3 \text { Professional Competence, Work Discipline, Teacher Performance on } \\
\text { Work Productivity }\end{array}$ & Path coeffi-cient & $\boldsymbol{t}$ & Sig & $\boldsymbol{R 2}$ & $\boldsymbol{F}$ & Sig \\
\hline Variable & 0.182 & 2.08 & 0.04 & & & \\
\hline Professional Competence & & 9 & 0 & 0.49 & 24.64 & 0.000 \\
& 0.588 & 7.00 & 0.00 & 0 & 9 & \\
Work Discipline & & 2 & 0 & & & \\
\hline
\end{tabular}


Nisa W, 2020 / The contribution of professional competence through the work discipline and performance

\begin{tabular}{llll}
\hline Teacher Performance & 0.172 & 2.03 & 0.04 \\
& & 4 & 5 \\
\hline
\end{tabular}

Table 5. Summary of decisions on hypothesis testing H1, H2, H3, H4, H5, H6

\begin{tabular}{lcl}
\hline \multicolumn{1}{c}{ Hypotheses } & $\boldsymbol{p}$ & Decision \\
\hline $\begin{array}{l}\text { There is a direct contribution of professional competence on work } \\
\text { discipline }\end{array}$ & 0.246 & Accepted \\
\hline $\begin{array}{l}\text { There is a direct contribution of professional competence on } \\
\text { teacher performance }\end{array}$ & 0.269 & Accepted \\
\hline $\begin{array}{l}\text { There is a direct contribution to professional competence on work } \\
\text { productivity }\end{array}$ & 0.182 & Accepted \\
$\begin{array}{l}\text { There is a direct contribution of work discipline to teacher perfor- } \\
\text { mance }\end{array}$ & -0.006 & Rejected \\
\hline $\begin{array}{l}\text { There is a direct contribution of work discipline to work productiv- } \\
\text { ity }\end{array}$ & 0.588 & Accepted \\
\hline $\begin{array}{l}\text { There is a direct contribution of teacher performance to work } \\
\text { productivity }\end{array}$ & 0.172 & Accepted \\
\hline
\end{tabular}

Table 6. Summary of decisions on hypothesis testing H7, H8, H9, H10

\begin{tabular}{lcc}
\hline \multicolumn{1}{c}{ Hypotheses } & $\boldsymbol{p}$ & Decision \\
\hline $\begin{array}{l}\text { There is an indirect contribution of professional competence } \\
\text { through work discipline to performance }\end{array}$ & -0.0014 & Rejected \\
\hline $\begin{array}{l}\text { There is an indirect contribution of work discipline through } \\
\text { performance to work productivity }\end{array}$ & -0.0010 & Rejected \\
\hline $\begin{array}{l}\text { There is an indirect contribution of professional competence } \\
\text { through work discipline on work productivity }\end{array}$ & $\begin{array}{c}0.246 \times 0.588 \\
=0.144\end{array}$ & Accepted \\
\hline $\begin{array}{l}\text { There is an indirect contribution of professional competence } \\
\text { through intermediary teacher performance on work produc- }\end{array}$ & $=0.269 \times 0.172$ & Accepted \\
tivity & & \\
\hline
\end{tabular}

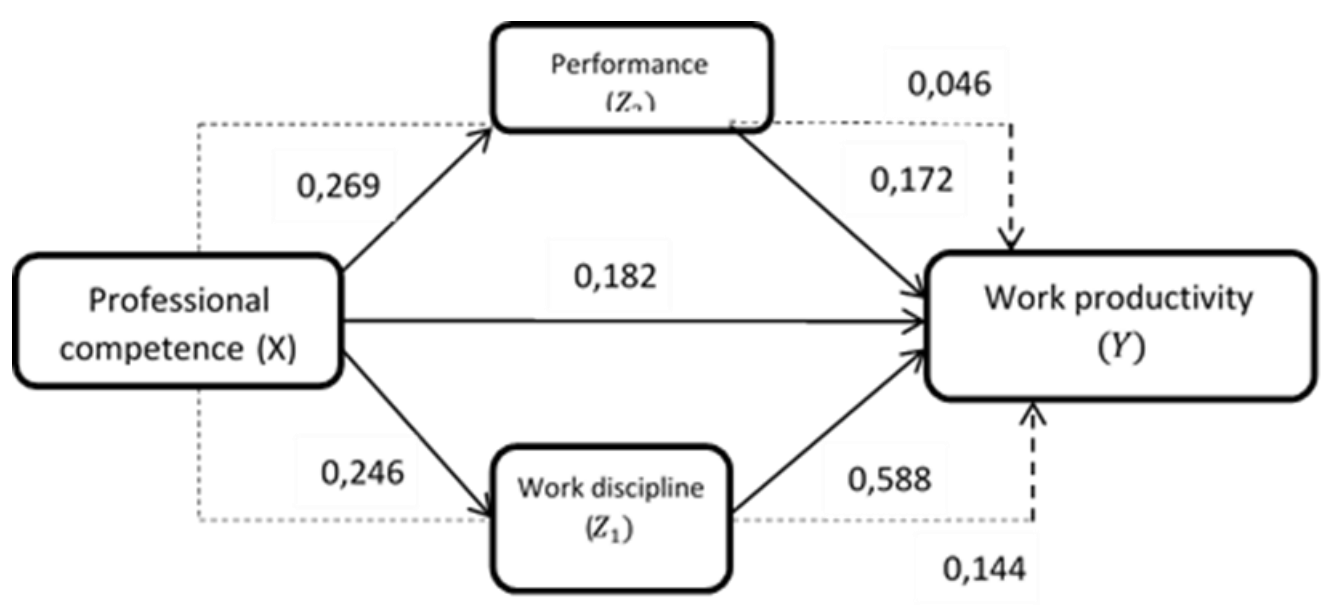

Figure 1. Final contribution between research variables 


\section{Conclusion and Recommendation}

Based on the result of data analysis and discussion as described above, it can be concluded as follow:

1. Professional competence and teacher performance in Public Elementary School in Tabunganen Subdistrict are in good classification, while the work discipline is in very high classification, and work productivity is in medium classification.

2. There is a direct contribution of professional competence to work productivity and work discipline to work productivity and teacher performance to work productivity.

3. There is an indirect contribution of professional competence through the work discipline to work productivity and the performance to work productivity.

Based on the results of the research that has been done, the researcher gives the following suggestions:

1. For teachers of the Public Elementary Schools in Tabunganen SubDistrict, to upgrade the professional competence, to improve discipline in time, and to produce useful scientific work to improve the teacher work productivity.

2. For principals in the Public Elementary Schools in Tabunganen SubDistrict, it is recommended to increasing evaluating and supervision programs to improve learning quality in the school.

3. For further researchers, it is suggested to be able to examine other factors that can also affect a larger population, so that other factors contributed to teacher work productivity can be identified.

\section{Acknowledgment}

Acknowledgment The author thanks to the Lecturer in Education Management Master Program that has provided input to the author since researching until this article can be published. Hopefully to all who helped and contributed to completing this research has been rewarded by Allah SWT.

\section{References}

Ahmed, M. H. (2012). A Study of Factors Affecting the Professional Performance of Teachers at Higher Education Level in Khyber Pakhtunkhwa. Academic Research International, Vol 2(2), 1-9.

Aslamiah. (2012). Menuju Kepala Sekolah Efektif dari Teoritis ke Praktis. Rumah Pengetahuan.

Berberick, D. M., Clementson, C. J., Hawkinson, J. K., \& Rolandson, D. M. (2016). A Comparison of Principal Practices and Music Educator Perceptions Regarding Teacher Evaluation. Bulletin of the Council for Research in Music Education, (209), 43-62.

Blackman, D., West, D., O'Flynn, J., Buick, F., \& O'Donnell, M. (2015). Performanca Management: Creating High Performance, not High Anxiety. In Wanna J., Lee H., \& Yates S. (Eds.), Managing Under Austerity, Delivering Under Pressure: Performance and Productivity in Public Service (pp. 79-102). ANU Press.

Bode, K. (2012). Literary Studies in the Digital Age. In Reading by Numbers: Recalibrating the Literary Field (pp. 7-26). London; New York; Delhi: Anthem Press.

Bull, P., Patterson, G., Dunston, Y., Wilbur, G., \& Simpson, C. (2017). Competency-based Education: The New Frontier in Teacher Education. In Solér M. (Ed.), Proceedings of the UNC CBE Summit 2017 (pp. 33-54). University of North Carolina Press.

Butter, R., \& Hermanns, J. (2011). Impact of experienced professionalism on professional culture in probation. European Journal of Probation, 3(3), 31-42. doi: $10.1177 / 20662203110030030$

Carpenter, D., \& Noller, S. (2010). Measuring Charter School Efficiency: An Early Appraisal. Journal of Education Finance, 35(4), 397-415.

Cohen-Scali, V. (2012). Competence Evaluation Processes in Adult Education. In Cohen-Scali V. (Ed.), Competence and Competence Development (pp. 73-94). Opladen; Berlin; Toronto: Verlag Barbara Budrich.

Costaa, C., Cardosob, A. P., Limac, M. P., Ferreirad, M., \& Abrantes, J. L. (2015). Pedagogical interaction and learning performance as determinants of academic achievement. Procedia - Social and Behavioral Sciences, 171, 874-881. doi:10.1016/j.sbspro.2015.01.203

Darko, C., Occhiali, G., \& Vanino, E. (2018). he Chinese Are Here: Firm Level Analysis of Import Competition and Performance in Sub-Saharan Africa. (Rep.)Fondazione Eni Enrico Mattei (FEEM).

Dunleavy, P. (2015). Public Sector Productivity: Puzzles, Conundrums, Dilemmas, and Their Solutions. In Wanna J., Lee H., \& Yates S. (Eds.), Managing Under Austerity, Delivering Under Pressure: Performance and Productivity in Public Service (pp. 25-42). ANU Press. 
Emmerichs, R., Marcum, C., \& Robbert, A. (2004). Context: Organizational and Human Capital Strategic Planning. In An Executive Perspective on Workforce Planning (pp. 1322). Santa Monica, CA; Arlington, VA; Pittsburgh, PA: RAND Corporation.

Engelbrecht, L. M. (2016). Perception on Teacher Productivity: Comparing The Cases of South Africa and South Korea. Dissertation.

Fenwick, T., \& Edwards, R. (2016). Exploring the impact of digital technologies on professional responsibilities and education. European Educational Research Journal, 15(1), 117 -131. doi:10.1177/1474904115608387

Gomes, F. (2005). Manajemen Sumber Daya Manusia. Yogyakarta: Andi Offset.

Gonzalez, G., Karoly, L., Constant, L., Salem, H., \& Goldman, C. (2008). Human Resource Challenges and Reform Efforts in Qatar, UAE, Oman, and Lebanon. In Facing Human Capital Challenges of the 21st Century: Education and Labor Market Initiatives in Lebanon, Oman, Qatar, and the United Arab Emirates: Executive Summary (pp. 29-46). RAND Corporation.

Hamda, S., \& Dalle, J. (2011). Relationship between service quality and satisfaction in distance learning unit program Indonesia Open University Banjaramsin. Asian Association of Open Universities Annual Conference (AAOU) (pp. 1-6). Penang: Asian Association of Open Universities .

Hamdani. (2017). Contribution of competence and perceptions of learning supervision on teacher work productivity. Invotek , 17(2),61-66.

Hariandja, M. T. (2005). Manajemen Sumber Daya Manusia. Jakarta: PT Grasindo.

Houck, E., Rolle, R., \& He, J. (2010). Examining School District Efficiency in Georgia. Journal of Education Finance, 35(4), 331-357.

Juvonen, J., Le, V., Augustine , C., \& Constant, L. (2004). Promoting Teacher Competence Through Training. In Focus on the Wonder Years: Challenges Facing the American Middle School (pp. 73-83). Santa Monica, CA; Arlington, VA; Pittsburgh, PA: RAND Corporation.

Kadarisman, M. (2011). The Effect of professionalism and competence on the performance of regional representatives council. Journal of Administrative Science \& Organization, 18(1), 53-62.

Kattenbelt, C. (2010). Intermediality in Performance and as a Mode of Performativity. In Kattenbelt C., Bay-Cheng S., Lavender A., \& Nelson R. (Eds.), Mapping Intermediality in Performance (pp. 29-37). Amsterdam: Amsterdam University Press.

Kelimeda, Hairudinor, Ridwan, M. N., \& Dalle, J. (2018). The effect of motivation, job satisfaction and job disciplinetoward employee performance of PT. Buma Perindahindo at Lng Tangguh Site, Teluk Bintuni Regency, West Papua, Indonesia. European Journal of Human Resource Management Studies, 2(1), 49-73.

Kim, P. (2016). Innovating training and development in government: The case of South Korea. In Podger A. \& Wanna J. (Eds.), Sharpening the Sword of State: Building executive capacities in the public services of the Asia-Pacific (pp. 125-140). Australia: ANU Press.

Kirby, S., McCombs, J., Barney, H., \& Naftel, S. (2006). NE in the Context of the Broader Teacher Education Reform Effort. In Reforming Teacher Education: Something Old, Something New (pp. 11-28). Santa Monica, CA; Arlington, VA; Pittsburgh, PA: RAND Corporation.

Klerman, J. (2005). Measuring Performance. In Klitgaard R. \& Light P. (Eds.), High-Performance Government: Structure, Leadership, Incentives (pp. 343-380). Santa Monica, CA; Arlington, VA; Pittsburgh, PA: RAND Corporation.

Krajewska, A. (2019). Didactic Cooperation between Teachers and Students in Higher Education: Utopia or Real Opportunity? In Kowalczuk-Walêdziak M., KorzenieckaBondar A., Danilewicz W., \& Lauwers G. (Eds.), Rethinking Teacher Education for the 21st Century: Trends, Challenges and New Directions (pp. 300-316). Opladen; Berlin; Toronto: Verlag Barbara Budrich.

Lauwers, G. (2019). Reshaping Teacher Training to Get the Right Education System for a Knowledge Society. In Lauwers $G$., Kowalczuk-Walêdziak M., Korzeniecka-Bondar A., \& Danilewicz W. (Eds.), Rethinking Teacher Education for the 21st Century: Trends, Challenges and New Directions (pp. 43-53). Opladen; Berlin; Toronto: Verlag Barbara Budrich.

Ndugu, M. (2014). Quality and Productivity of Teachers in Selected Public Secondary Schools in Kenya. Mediterranean Journal of Social Sciences Vol 5(5).

Newman, C., Page, J., Rand, J., Shimeles, A., \& Söderbom, M. (2016). Productivity, Exports, and Competition. In Made in Africa: Learning to Compete in Industry (pp. 85-108). Washington, D.C.: Brookings Institution Press.

Ng, E. S., Schweitzer, L., \& Lyons, S. T. (2010). New generation, great expectations: a field studyof the millennial generation. Journal of Business and Psychology, 25, 281292. doi:10.1007/s10869-010-9159-4

Normianti, Aslamiah, \& Suhaimi. (2019). Relationship of Transformational Leaders of Principal, Teacher Motivation, Teacher Organization Commitment With Performance of Primary School Teachers In Labuan Amas Selatan, Indonesia. European Journal of Education Studies, 5(11), 1-10. 
Novozhenina, A., \& Pinzon.M.M. (2018). Impact of a Professional Development Program on EFL Teachers' Performance. How, 25(2), 113-128.

Rizalie, A. M. (2017). Implementasi Manajemen Berbasis Sekolah untuk Peningkatan Mutu Pendidikan di Sekolah dan Madrasah. Jurnal Paradigma 11(2).

Sabzian, F., Gilakjani, A. P., \& Sodouri, S. (2013). Use of technology in classroom for professional development. Journal of Language Teaching and Research, 4(4), 684-692. doi:10.4304/jltr.4.4.684-692

Santoro, N., Reid, J., Crawford, L., \& Simpson, L. (2012). Teaching Indigenous teachers: Valuing diverse perspectives. In Basit T. \& Tomlinson S. (Eds.), Social inclusion and higher education (pp. 255-272). Bristol: Bristol University Press.

Suprihatiningrum, J. (2016). Guru Profesional: Pedoman Kinerja, Kualifikasi \& Kompetensi Guru. Jogjakarta: Ar-Ruzz Media.

Suriansyah, A. (2014). Hubungan Budaya Sekolah, Komunikasi, dan Komitmen Kerja terhadap Kinerja Guru Sekolah Dasar Negeri. Jurnal Cakrawala Pendidikan.

Suriansyah, A. (2015). Pengembangan Pembelajaran Berbasis TIK. Jurnal Paradigma 10(2), 23-19.

Suriansyah, A. (2015). Strategi Pembelajaran. Jakarta: Raja Grafindo Persada.

Susanto, P. (2016). Produktivitas Sekolah. Bandung: Alfabeta.

Synar, E., \& Maiden, J. (2012). A Comprehensive Model for Estimating the Financial Impact of Teacher Turnover. Journal of Education Finance, 38(2), 130-144.
Tóth-Pjeczka, K., Rapos, N., \& Szivák, J. (2019). Components, Models and Operational Mechanisms of Teacher Collaboration. In Kowalczuk-Walêdziak M., KorzenieckaBondar A., Danilewicz W., \& Lauwers G. (Eds.), Rethinking Teacher Education for the 21st Century: Trends, Challenges and New Directions (pp. 283-299). Opladen; Berlin; Toronto: Verlag Barbara Budrich.

Van Weeren, J. (2004). Assessing Professional Competence: Some Basic Considerations. Educational Technology, 44(1), 2833.

Wahyudi, I. (2012). Pengembangan Pendidikan. Jakarta: Prestasi Pustaka Publisher.

Weintraub, R. (2012). BackTalk: Lessons on leadership. The Phi Delta Kappan, 93(7), 80-80.

Yamin-Ali, J. (2019). Let It Begin with Me: The Forging of a Professional Teacher Educator Self. In KowalczukWalêdziak M., Korzeniecka-Bondar A., Danilewicz W., \& Lauwers G. (Eds.), Rethinking Teacher Education for the 21st Century: Trends, Challenges and New Directions (pp. 54-78). Opladen; Berlin; Toronto: Verlag Barbara Budrich.

Yusuf, F., Olufunke, Y., \& Valentine, M. (2015). Causes and Impact of Stress on Teacher's Productivity as Expressed by Primary School Teachers in Nigeria. Creative Education.

Zachos, D. T., Delaveridou, A., \& Gkontzou, A. (2016). Teachers and School "Discipline" in Greece: A Case Study. European Journal of Social Sciences Education and Research, 3(3), 819. 